\title{
Research Libraries in an International Setting: Requirements for Expanded Resource Sharing
}

\author{
Richard M. Dougherty
}

Resource sharing has expanded significantly in the past decade. While the benefits have been obvious, the mounting costs of lending and borrowing are causing serious concern. Higher costs and the physical deterioration of library research collections are likely to influence not only national but also international resource-sharing agreements. In this article the roles and structures of several European national lending systems are described. The purpose is to find useful models to guide future developments both at home and abroad. The author suggests that a new basis for measuring the performance of interlending systems needs to be established in order to ensure equity and to limit resource sharing to specialized materials that support the research efforts of faculty and doctoral students.

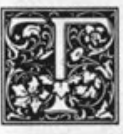

he fact that no research library can be self-sufficient has become universally accepted and explains in part why university librarians have devoted so much time and energy in recent years toward improving resource-sharing arrangements and interlending systems among libraries. Much progress can be documented, and librarians in most Western countries can point with justifiable pride to significant programs intended to facilitate national programs of sharing library resources. Programs such as the International Federation of Library Associations' (IFLA) UAP (Universal Availability of Publications) reflect but one of the current efforts to extend resource sharing beyond national borders.

Recent resource-sharing developments, though encouraging, have also surfaced issues that, if left unresolved, could lead to the gradual erection of restrictive barri- ers. I am referring to concerns such as the mounting costs of lending and borrowing and the growing evidence that the collections of research libraries are deteriorating physically. It should be a priority professional goal to forge agreements that will endure and will ensure the perpetuation of unfettered resource sharing among the Western world's research libraries.

Library resource sharing should not be taken for granted. It was not too long ago that many government officials and academic officers viewed such sharing as a substitute for building adequate research library collections. This behavior pattern was described by Jefferson, as he pointed out that in the postwar period interlending between libraries was widely interpreted as a synonym for library cooperation. ${ }^{2}$ One undesirable implication of this interpretation was the use of interlending as a prop by some institutions. Instead of being used as a means of temporarily sup-

Richard M. Dougherty is director of libraries at the University of Michigan, Ann Arbor, Michigan 48109. This article is based on a paper delivered at the Research Libraries Group International Conference, Stanford, California, October 2, 1984. 
plementing the resources of a library in a positive manner to insure that the more specialized or infrequently used books at the fringe of a library's book collection development policy were available to its readers, too often the interlending system was used as a substitute for local ownership. In the United States this misapplication of the intent of resource sharing has actually inhibited the growth of some research libraries. One of my colleagues once expressed this philosophy as a "sharing of poverty." If carried to an extreme, one might speculate on how scholars would obtain research materials if all libraries deferred purchases, depending on the largesse of others.

The philosophy espoused by organizations such as the Research Libraries Group (RLG) clearly places resource sharing in a more appropriate perspective. RLG's goal is to insure that books at the margin of a library's book selection policy can be made available to readers. For example, at the University of Michigan a faculty member may receive material on the Basque language through RLG that would not otherwise be available. (RLG is a nonprofit corporation owned and operated by its members. The creation of RLG in 1974 was "an effort by research universities and independent research libraries to manage the transition from locally selfsufficient and independently comprehensive collections to a system of interdependencies that will preserve and enhance our capacity for research in all fields of knowledge and improve our ability to locate and retrieve relevant information. ${ }^{\prime \prime 3}$

The contributions of IFLA's UAP program have sharpened the understanding of international agencies, library officials, and users of libraries to both the potential and the limitations of resource sharing. The concept behind the UAP program is straightforward. It seeks to achieve "the widest possible availability of published material . . . to intending users, wherever and whenever they need it." ${ }^{\prime 4}$ Although the overarching goal of the UAP program is unattainable, the concept has energized efforts to improve availability in a number of countries, and consequently its impact will nudge librarians closer toward the ideal of universal availability than otherwise might have been possible.

\section{THE CURRENT SCENE}

A review of recent literature reveals that resource sharing and interlibrary lending have expanded rapidly throughout the industrialized world. While the growth of interlending seems to be universally consistent, the structure of national interlending systems that emerged varies greatly from country to country. For example, in the United Kingdom the resource-sharing system is based on a central lending collection at the British Lending Library Division (covering all significant serials and reports and all significant recent English-language monographs), supported by a system of national and regional union catalogs and several large libraries.

In the Federal German Republic, the Deutsche Forschungsgemeinschaft organized in 1949 a supraregional system of literature provision based on two state libraries, four central subject libraries, fifteen university libraries, and thirteen special libraries. In the late 1950 s seven regional union catalogs were developed; these provide access to the holdings of academic libraries in each region. The intention was to create a more equitable distribution of lending. In the 1950s and 1960s, every request had to pass through the nearest regional union catalog. Since that time, strict adherence to the regional protocol has given way to direct requesting. ${ }^{5}$

In Sweden and Denmark the systems are essentially decentralized, although the Swedish system evidences some elements of centralization. Provision of loans to Swedish public libraries takes place through three interlibrary loan centers. Regional central libraries cooperate in planning the acquisition of special works. Advanced and highly specialized materials are provided by the ILL lending centers, and research libraries are involved only as a last resort. ${ }^{6}$ In Denmark the system is based on a network of public libraries and on research libraries for some specialized subjects. ${ }^{7}$ In the Netherlands one finds another type of structure. Union 
catalogs are maintained by the Royal Library and the Technical University at Delft. Nonetheless, research libraries lend freely to others, and thirteen large public libraries provide regional support for scholarly literature in their respective regions. ${ }^{8}$

And finally, in the United States a network of more than one hundred research libraries cooperates in consortia such as RLG and OCLC, but resource sharing in the United States is largely decentralized. The diversity of systems that currently exists in the Western countries will have to be taken into account by those who plan future supranational programs of resource sharing and interlending systems. Planners will have to work within the organizational frameworks that currently exist.

Now, as we consider new approaches to international resource sharing, how can we build on the recent experiences of individual nations; which models are most appropriate to international resource sharing? This question is often raised in terms of operational effectiveness; but in the context of the international arena the questions of effectiveness may not be critical. Researchers have attempted to measure the effectiveness of various organizational structures, but no specific structure has shown itself to be superior under all circumstances. ${ }^{9}$ Furthermore, effectiveness alone is unlikely to convince a country to scrap or overhaul its existing system. Therefore, we can assume that any new international program of resource sharing must complement existing national or supranational plans.

Another problem to be considered is the fact that most national systems in western European countries are multitype library systems often dominated by public libraries. Research librarians cannot hope to restructure existing national interlending systems simply to accommodate their own needs. Again they will have to work within existing frameworks; nonetheless, it should be possible to accommodate the special needs of scholars if university librarians plan their programs carefully. In order to better understand the options available, it is worthwhile to review briefly some recent significant developments.

\section{THE GOLDEN AGE OF RESOURCE SHARING}

The impressive contributions of the British Lending Library and the more recent impetus provided by IFLA's UAP have already been cited. Less obvious, but also a contributing factor, has been the growth in the number and coverage of union catalogs in many countries. In the United States the most significant development has been the appearance of the automated interlibrary lending systems of OCLC and RLG. These systems, using records from databases containing over twenty million titles, provide information about the holdings of libraries, reduce the paperwork associated with interlending, speed up turnaround times, and enable librarians to monitor performance in a manner never before possible.

These advancements ushered in the "golden age" of resource sharing, and most librarians can point to these achievements with justifiable pride. But at the same time one should not ignore the danger signals that loom on the horizon. The heavy volume of interlending is straining the ability of many libraries to supply materials in a timely manner, and longer delays may become common along with the complaints of researchers whose expectations of performance are now higher than was previously the case. (Restrictions in transborder data flows could also prove to be a serious obstacle to international resource-sharing programs, but this article focuses on the sharing of publications and not the data that represent publications.)

The impact of the rapidly escalating volume of resource-sharing traffic has been very dramatic in the United States. First, the success in providing location information about publications stimulated levels of demand that has outstripped the ability of many libraries to deliver documents in a timely manner. This imbalance might be characterized as a collision of two eras: the technological age of bibliographical access colliding with the horse-and-buggy era of document delivery. Second, the heavy 
volume of interlending coupled with oncampus use of collections is accelerating the physical deterioration of collection materials. The acid content of paper in many publications is rendering them too brittle for use, and some libraries are already restricting interlending or even local use of endangered titles.

The greatest threat to the continued unfettered exchange of materials, however, could be the dramatic increase in volume itself. Several years ago Frederick Kilgour analyzed the impact of OCLC on the lending activities of thirty-seven libraries located in the state of Ohio. Kilgour found that the lending rates of the small libraries had increased as much as 1,437 percent and in the largest libraries the rate, though much more modest, was an impressive 85.6 percent. $^{10}$ Richard De Gennaro recently observed that the "rationale for free interlibrary loan no longer holds in the new, high-volume, and more demanding resource sharing environment that is being created by the successful computerization of the interlibrâry loan location and communication functions through OCLC and other on-line networks." "11 De Gennaro is an astute observer of the library scene and his cautions should be heeded.

\section{PATTERNS OF COLLECTION USE}

Let us for a moment consider the dynamics of collection use and how these factors influence resource sharing among research libraries. First, researchers have found that large segments of collections are infrequently used. This assertion is based on several well-known studies that found that about 20 to 25 percent of a university library collection will account for 80 percent of formal circulation within a given year. ${ }^{12}$ This pattern of usage also reflects the phenomenon identified by the Bradford-Zipf law.

A second dynamic of collection usage is highlighted by the data presented by Thomas Galvin and Allen Kent in what has become known as the "Pittsburgh studies." The work of Galvin and Kent suggests that even for a multiyear period, a sizable proportion of a research library's collection may not be used. Galvin and Kent's data showed that almost half of the collections in the Pittsburgh University libraries showed no evidence of formal lending over a five-year period. ${ }^{13} \mathrm{Al}$ though the specific findings of the Pittsburgh studies have been challenged by numerous researchers, ${ }^{14}$ most librarians do not challenge the central thesis that a sizable proportion of the collection showed little evidence of usage.

A third dynamic is that interlibrary lending accounts for a very small proportion of total lending activity in a research library, or conversely, roughly more than 99 percent of all lending is accounted for by intracampus activity. This pattern of usage has led some librarians to wonder whether there is a danger of spending a disproportionately large share of scarce resources to satisfy a very small portion of lending activity. ${ }^{15}$

The University of California has committed millions of dollars to link its nine campus libraries through a union catalog. The objective of the university is to stimulate increased resource sharing. But even if successful, interlibrary lending/borrowing is unlikely to account for more than 2 percent of a campus library's total lending and borrowing. This points out an unmistakable irony that should not be overlooked. Libraries and their parent institutions appear willing to spend millions to double resource sharing from 1 to 2 percent of the total borrowing activity. But can the campus libraries afford to pay for the increased lending/borrowing traffic? Unrestrained interlending could add several million dollars in additional costs to services offered by the nine campus libraries. If the University of California libraries are expected to absorb these additional costs, other services such as reference, bibliographic instruction, and preservation would inevitably suffer. The California model sets forth the current dilemma most libraries face in attempting to balance the levels of service that librarians would like to provide against the economic realities of this period of fiscal constraint.

Rationalized interlending among re- 
search libraries would be facilitated if each library carefully analyzed the dynamics of its current borrowing activity, identifying specifically which categories of publications are currently borrowed and for what purposes, e.g., work on thesis research. A sampling of interlibrary borrowing requests drawn from the borrowing transactions at the University of Michigan several years ago revealed a pattern of borrowing activities that probably typifies the patterns in libraries on both sides of the Atlantic. Most transactions fell into two distinct categories. In the first were the majority of requests, which included materials commonly held by libraries; these usually could be obtained more quickly and cheaply from a college library situated closer than the university to the requesting institution. In the second category were the requests for obscure journals, specialized monographs, and dissertations. These items are normally supplied by other large universities, national lending centers such as the British Lending Library Division and the Center for Research Libraries, or from the collection of a library in another country.

The difference in criteria one uses to judge the effectiveness of resource sharing is what distinguishes between these two categories. In the case of the commonly held materials, the customary indicators of performance are speed, cost per transaction, and reliability, whereas in the second category a higher premium is placed on retrieval than on cost per transaction. Although this writer is not able to assign precise proportions, he suspects that the vast majority of interlibrary borrowing traffic for all academic institutions falls into the first category and that only a minority of borrowing transactions truly requires the resources of national lending agencies or large research libraries.

If a specialized interlending system takes into account the way research library collections are normally used and the existing nature of interlending activities, it should be possible to create an effective and affordable interlending network that spans national boundaries. Thus the writer suggests that the research library community identify the categories of materials most essential to resource sharing among research libraries. These categories might include foreign dissertations, publications of the developing world, and publications commonly referred to as "gray" literature. Requests for journals and monographs easily obtainable from local sources should not be allowed to clog the channels of interlending, and thus these requests would be excluded through policy declaration.

\section{NEW BASES FOR MEASURING PERFORMANCE}

Objective assessment of existing interlending programs usually emphasizes how much is lent rather than evaluating what is lent. In a research library network, the emphasis might better be on what is borrowed rather than how much is lent. A philosophy that translates into "more is better" should give way to a philosophy that places emphasis on satisfaction rate, speed, and cost. Furthermore, in the context of research library consortia greater effort should be made to structure lending and borrowing policies so that each institution contributes its fair share to the effort. If, for example, long-term differences develop between lending and borrowing among consortium members, net borrowers have an obligation to reimburse institutions that are the net lenders, in other words, some mechanism to establish equity is necessary. The failure to strike an equitable balance may inevitably jeopardize any program that is based, not on equity but (although unintentionally) on parasitic relationships.

What conclusions can be drawn from the current state of affairs? Escalating costs, the growing concern over the physical deterioration of collections, and the limitations of document delivery need to be given prominent attention as the groundwork for national and supranational resource sharing is formulated. It should be possible to create effective interlending arrangements within the constraints cited if resource sharing among research libraries is designed exclusively to support the research efforts of faculty and 
doctoral students. If resource sharing is limited to specialized materials-most of which fall into the category of unused or infrequently used materials (e.g., publications that often reflect a narrow focus of research, require specialized knowledge, or a language facility not widely held), then the volume of lending should remain at manageable levels. Thus the probabilities for the long-term success of resource sharing may be enhanced.

\section{CHARTING A FUTURE COURSE}

I will conclude this review by introducing briefly what may become the next major challenge to resource sharing and library cooperation: the coordination of collection development.

A recent survey reported by Judith Collins and Ruth Finer suggests there has not been a great deal of coordinated acquisitions planning on a national level. ${ }^{16}$ There have been exceptions such as the cooperative efforts funded by the Deutsche Forschungsgemeinschaft. In the United States considerable planning has been accomplished by RLG as evidenced by its collection conspectus project, ${ }^{17}$ but as yet very little coordinated collection activity has actually occurred.

Successful coordinated acquisition programs may elude libraries for many years. This type of activity, which seems so logical, raises a host of complicated political issues in the minds of faculty. National and institutional politics and the need for university librarians to respond to the requests of local constituencies are only two of the barriers to coordinated collection development that must be surmounted. For example, it would be difficult to explain to an irate historian why the library cancelled journals important to local historians but continued to subscribe to periodicals intended to support researchers at distant institutions. The goals of cooperative acquisition programs will be achieved only if we can alter the attitudes of those who use university library collections. The benefits of such cooperation must first be demonstrated before we can expect users to change attitudes and behaviors. And in order to demonstrate success, we will need funds earmarked specifically for the purpose of funding cooperative acquisitions.

Two recent conferences, attended by foundation officers, faculty, university administrators, and library directors, focused on the considerable challenge of cooperation in today's political and economic context. The mandate exists to make materials available to scholars, but the necessary redefinition of cooperation has not been embraced nor the implications understood. Jim Haas describes the mandate as it was discussed at these conferences.

The principle of shared responsibility for building and maintaining comprehensive resources for research and the corollary of assured access by scholars to needed materials and information was assumed [by participants] without question. National distinction is the aggregation of institutional strength, and the issue for attention concerns the retention of strength in chosen areas by individual libraries in a setting of rising costs, growing quantities of recorded information in all forms, and dynamic demand. The key seems to be to create a national setting which will (1) provide more options for individual libraries, (2) provide access to more resources by more users, and (3) improve prospects for building and maintaining, nationally, unmatched resources for research. ${ }^{18}$

Obviously the more difficult challenge will be to "sell" the consequences of this mandate, for it, to some extent, will require difficult decisions in determining the locus of collecting activity within a cooperative organization.

At the present time university libraries are trapped in a vicious circle. The ideals of cooperation are supported by the economic necessity but challenged by the political reality. We need the farsighted leadership of governmental officials and academic officers who are willing to follow the lead of the Federal Republic of Germany, which had the foresight to provide the incentives necessary to stimulate shared collection development as well as incentives for library users to accept a nontraditional approach to collection development among research libraries.

I believe the long range goal of univer- 
sity libraries in the United States and western European countries should be to enhance shared-collection development, expand bibliographic access, and provide efficient, affordable delivery of docu- ments. To the extent these complementary objectives are met, we can gauge our profession's success at fulfilling the IFLA ideals of universal bibliographic control and availability of publications.

\section{REFERENCES AND NOTES}

1. For those not familiar with recent developments on the international scene, I can recommend the writings of Maurice Line, who has written extensively on the subject of interlending and resource sharing.

2. George Jefferson, Library Co-operation (London: Andre Deutsch, 1977), p.32.

3. RLG in Brief (Stanford, Calif.: Research Libraries Group, Dec. 1984), p.2.

4. International Federation of Library Associations and Institutions. Medium-Term Programme 1981-1985 (The Hague: IFLA, 1982), p.59.

5. R. Landwehrmeyer, "A Planned Decentralized Solution for National Document Supply: The Federal Republic of Germany," Interlending Review 9 (1981).

6. Antonio A. Briquet de Lemos, Descriptions of Interlibrary Lending in Various Countries and a Bibliography of Interlibrary Lending (Boston Spa: IFLA Office for International Lending, 1980); Tomas Lidman, "Interlibrary Lending in Sweden and Plans for a Decentralized System of SubjectSpecialized Libraries," Interlending and Document Supply 11:21-23 (1983).

7. International Federation of Library Associations. Office for International Lending, A Brief Guide to Centres of International Lending and Photocopying, by Anne M. Digby and Barry P. Thompson (Boston Spa: IFLA Office for International Lending, 1975).

8. Briquet de Lemos, Descriptions of Interlibrary Lending in Various Countries and a Bibliography of Interlibrary Lending.

9. See, for example: William Y. Arms, "Models for Interlibrary Lending," Interlending Review 7:130-36 (1979); and Maurice B. Line, "National Interlending Systems: Existing Systems and Possible Models," Interlending Review 7:42-46 (1979).

10. Frederick G. Kilgour, "Interlibrary Loans On-Line," Library Journal 104:463 (Feb. 15, 1979).

11. Richard De Gennaro, "Resource Sharing in a Network Environment," Library Journal 105:353 (Feb. 1, 1980).

12. Richard W. Trueswell, "Some Behavioral Patterns of Library Users: The 80/20 Rule," Wilson Library Bulletin 43:458-61 (Jan. 1969).

13. Thomas J. Galvin, and Allen Kent, A Cost-Benefit Model of Some Critical Library Operations in Terms of Use of Materials. Final Report (University of Pittsburgh, Apr. 15, 1978).

14. "Pittsburgh University Studies of Collection Usage: A Symposium," Journal of Academic Librarianship 4:60-70 (May 1979).

15. Samuel Rothstein, "The Extended Library and the Dedicated Library: A Sceptical Outsider Looks at Union Catalogues and Bibliographic Networks," The Future of the Union Catalogue: Proceedings of the International Symposium on the Future of the Union Catalogue, Cataloging \& Classification Quarterly, 2:110 (1982).

16. Judith Collins and Ruth Finer, "National Acquisition Policies and Systems: An International Perspective," Interlending Review 10:111-18 (1982).

17. The Conspectus project is described in detail in Nancy E. Gwinn and Paul H. Mosher, "Coordinating Collection Development: The RLG Conspectus," College \& Research Libraries 44:128-40 (Mar. 1983).

18. Two Reports on Research Libraries (Washington, D.C.: Council on Library Resources, Nov. 1983), p.17. 